\title{
Persistent Organic Pollutant: A Review on the Distribution of Polycyclic Aromatic Hydrocarbons (PAHs) in Aquatic Ecosystem
}
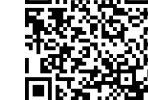

\author{
Ejike Joel Ejiako $^{1 *}$, Okechukwu Uzoma Iheme ${ }^{2}$ and Camillus Uchenna Okonkwo ${ }^{3}$ \\ ${ }^{1}$ Department of Pure and Applied Chemistry, University of Calabar, Nigeria
}

${ }^{2}$ Department of Soil Science and Technology, Federal University of Technology, Nigeria

${ }^{3}$ Department of Chemical Engineering, University of Benin, Nigeria

Submission: February 01, 2022; Published: February 15, 2022

*Corresponding author: Ejike Joel Ejiako, Department of Pure and Applied Chemistry, University of Calabar, Calabar, Cross River State, Nigeria

\begin{abstract}
Polycyclic aromatic hydrocarbons (PAHs) are a class of ubiquitous, carcinogenic and persistent organic pollutants. As persistent contaminants, they do not just pollute the immediate environment where they are released but travel from place to place. They have little degradability and are capable of reacting with other pollutants in the environment to form worse contaminants. It is shown in this work that PAHs are inevitably abundant in the sediment and water bodies as well as in fish. The concentration of PAHs in the aquatic environment could be attributed to the pollutants from the terrestrial ecosystem which eventually finds their way into the water bodies as effluents or run-offs. Sources and route source of some carcinogenic and mutagenic forms of PAHs were also considered and some notable and most dangerous PAHs were also classified in terms of sources. Evidences of bio-accumulation of this carcinogen abound and this poses serious trait to the free existence of living organisms both on land and in water. Combustion of oil, garbage, petroleum and petroleum products should be checkmated so as to reduce the accumulation of PAHs emanating from anthropogenic activities because the major concentration of PAHs in the environment is credited to anthropogenic source. Regular PAHs monitoring in the environment is advised and researchers should invest more energy towards discovering better and low cost effective means of PAHs contaminated air, soil and water remediation.
\end{abstract}

Keywords: PAHs; POPs; Anthropogenic; Bioconcentration; Pollution

\section{Introduction}

The earth on which man lives is composed of the atmosphere, lithosphere and hydrosphere which make up the biosphere. The biosphere does not only sustain lives but also serves as a dump site for all waste products which is recycled naturally without negatively impacting on the biotas [1]. However, industrialization, urbanisation, population increase and intensive agricultural activities have overloaded it beyond its capacity causing tremendous damage to the environment through the release of toxic chemicals and materials [2]. Persistent organic pollutants (POPs) are one of the toxic organic chemicals that are resistant to degradation biologically or chemically and can last for many years in the environment, travelling from point source to a very long distance. They accumulate in the food chain causing harm to both the environment and living organisms in it [3]. They include but not limited to the following; polycyclic aromatic hydrocarbons, polychlorinated biphenyls and organochlorine pesticides. This review focuses on the prevalence of polycyclic aromatic hydrocarbon on the aquatic environments with respect to the risks associated with its exposure to aquatic lives.

\section{Polycyclic Aromatic Hydrocarbons and Types}

Polycyclic aromatic hydrocarbons (PAHs) are chemical compounds consisting mainly of carbon and hydrogen. They are composed of multiple aromatic rings [4]. PAHs are a group of organic chemicals that occur naturally in coal, petroleum and petroleum products like gasoline. They also occur artificially through anthropogenic activities like combustion of oil, garbage, coal etc. [5]. The major source of exposure to PAHs to living organism is food and smoking followed by a minor contribution from inhalation of ambient air [6]. Long term exposure to PAHs could lead to serious health risks this is because their carcinogenic and genotoxic effects on human health. However, PAHs are 
widely used in making products such as agricultural products, pharmaceuticals, plastics, lubricants and many others which become potential hazards if they escape during production process into the environment or in industrial effluents [7]. Examples of PAHs include the following $1 H$-Phenalene, Tryphenylene, Perylene, Corannulene, Coronene, Ovalene [8]. The United State Environmental Protection Agency (USEPA 2008) enlisted about 16 priority PAHs as highly potential hazards in the environment.
Naphthalene, chrysene, benzo(b)flouranthene, benzo(k) flouranthene, benzo(a)pyrene(B(a)P), dibenz(a,h)anthracene. dibenzo(a.e)pyrene and dibenzo(a,l)pyrene anthanthrene are of particular note due to their carcinogenic and mutergenic properties. However, benzo(a)pyrene has been identified to be highly carcinogenic [9] and these prompted increasing concern about the concentration of these health threatening chemicals in the environment (Table 1).

Table 1: PAHs that are of great environmental concern.

\begin{tabular}{|c|c|c|c|}
\hline Acenaphthene & benz(a)anthracene & Dibenzo[a,h]anthracene & Mbenzo[k]flouranthene \\
\hline Acenaphthylene & Benzo(b)flouranthene & Fluoranthene & Naphthalene \\
\hline Anthracene & Benzo[g,h,i]perylene & Fluorene & Phenanthrene \\
\hline B[a]P & Chrysene & Indeno[1,2,3-cd]pyrene & Pyrene \\
\hline
\end{tabular}

\section{Sources of PAHs}

Sources of PAHs are grouped into two namely; Petrogenic and pyrogenic sources. Petrogenic sources are small, 2-3 rings, emanating from petroleum and petroleum products. They are acute toxic, genotoxic, low carcinogenic compounds. Pyrogenic PAHs are mainly larger, 4-6 rings compounds. They have lower acute toxicity, high mutagenicity and carcinogenicity. Figure 1 Summarizes the sources of some selected polycyclic aromatic hydrocarbons and their structures [10].

Group 1. Petrogenic source<smiles></smiles>

Naphthalene

Group 2. Pyrogenic source<smiles>CCCCCc1cccc2c1-c1ccc3c-2c1C=C3</smiles>

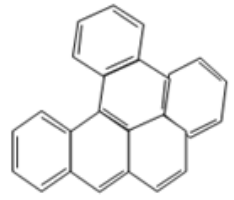

Dibenzo(a,l)pyrene<smiles></smiles>

Anthracene<smiles>CC(C)Oc1ccc2cccc3c2c1-c1ccc2ccccc2c1-3</smiles>

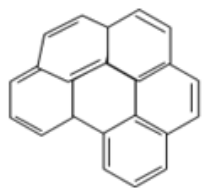

Benzo(g,h,i)perylene

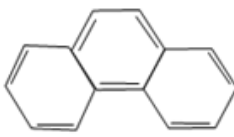

Phenanthrene<smiles>CC(C)(C)C1CCCCC1</smiles>

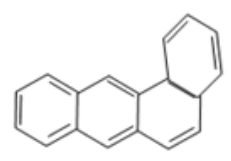

Benzoanthracene

Figure 1: Structures of some selected PAHs.

Polycyclic aromatic hydrocarbons are also of natural sources and anthropogenic sources ${ }^{[11]}$. Natural sources of PAHs include volcanic eruption, natural forest fire, decomposition of organic materials and oil seeps [11,12] Anthropogenic sources of PAHs are mainly incomplete combustion of organic materials and fuels (especially during industrial and domestic activities) example combustion of natural gas, processing of coal and petroleum, combustion of refuse, emission from motor vehicles, burning of firewood during cooking and tobacco smoking. Anthropogenic PAHs is the major source of PAHs. From the source of production,
PAHs are transported over a long distance. Study has shown that benzo[g,h,i]perylene (rings $>4$ ) has low mobility, while pyrene and benz(a)anthracene (4 ringed PAH) show relatively low mobility. PAHs with 3 rings (anthracene and phenanthrene) show relatively high mobility while those with 2 rings (naphthalene) have very high mobility [13] which accounts for its persistent characteristic. Aquatic environment happens to be the most unfortunate facet of the ecosystem. Very many amount of the environmental pollutant (air or land) empties into the water bodies either as atmospheric deposit (wet or dry) or land runoff [14] (Figure 2). 


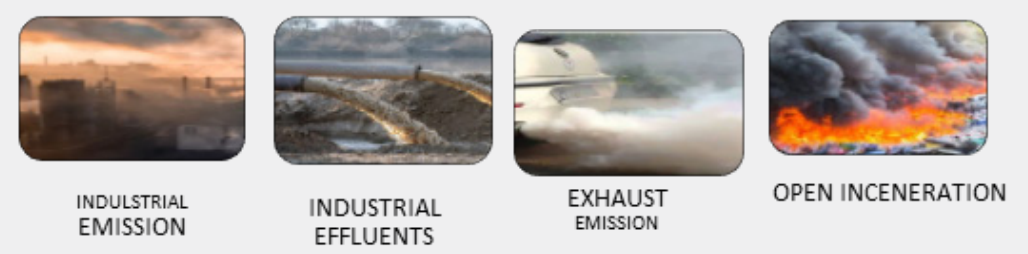

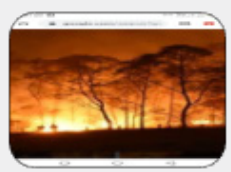

FOREST FIRE
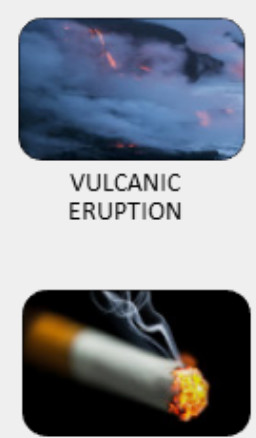

BURNING

CIGRETTE

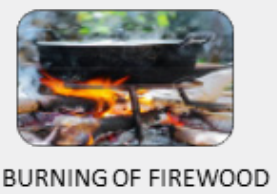

Figure 2: Different sources of PAHs.

\section{Prevalence of PAHS in Water and Sediments}

Carcinogenic polycyclic aromatic hydrocarbons (PAH's) are one of the classes of compounds that their distribution in aquatic environment has gained the interest of many researchers perhaps due to their harmful effect to humans as well as aquatic organisms [15]. Some published and unpublished works on water environment reported varying levels of water bodies' contamination with PAHs all over the world. Anthropogenic PAHs have been reported as the major contributor to the concentration of Aquatic PAHs, as a result of both industrial effluents, deposition of airborne particles, surface runoff and oil spillage which enter the aquatic environment, most of which accumulate in the bottom sediments [16]. Research on polycyclic aromatic hydrocarbons in water, sediment and fish from the Worri River at Ubeji Niger Delta, Nigeria showed that the river was contaminated with PAHs from possible oil spills from the refinery localized in that area. Out of about 16 PAHs investigated in water, sediment and fish tissues from Worri Rivers, 11 were identified in sediments and the rest in fish and water [17].

[18] Distribution of about 17 PAHs in water and sediment of Alau Dam in Borno State of Nigeria were determined. According to the results, source analysis indicated pyrogenic origin of all the PAHs. More so, PAHs levels in water samples were seen to be below the maximum allowable concentration (MACs) of 0.005$3.0 \mathrm{mg} \mathrm{L}^{-1}$. Though the risk assessment of the subject in water and sediment suggested a non adverse effects in the aquatic ecosystem, there is a possible adverse effect as a result of the persistency and accumulative nature if PAHs. [19] Some selected polycyclic aromatic hydrocarbons were reported in muscles of some samples of fish collected from Gonti river in India. The result showed dominance of low molecular weight PAHs over the high molecular weight PAHs. Naphthalene was reported as the most prevalent compound detected and also has the highest concentration in the samples. Some of the PAHs that were not detected were; benzo[k]fluoranthene, benzo(a)pyrene, and indeno(123-cd)pyrene + benzo(ghi)perylene. [20] The potential sources and ecotoxicological risks of 26 aliphatic hydrocarbons (AHs), 16 polycyclic aromatic hydrocarbons (PAHs) and total petroleum hydrocarbons (TPHs) were investigated in coastal water and sediments of Khark Island, SW Iran. Though the levels of these eco potential hazards were detected to be low, consistent environmental monitoring and control is recommended to reduce the pollution burden of PAHs in seawater [21]. The Distribution patterns of polycyclic aromatic hydrocarbons (PAHs) in the sediments was analyzed by collecting samples of sediments, monthly from eight shrimp shallow ponds for 6 months in wet and dry seasons at Mai Po Marshes Nature Reserve, Hong Kong. The results indicated that under wet season wet deposition and suspended particulates brought in by nearby rivers, such as the Peal River, served as an important source of PAHs entering Mai Po Marshes. This takes into account of the fact that PAHs can travel from place to place even from one country to another, in dry or wet seasons [22]. Reported high concentration of 16 priority PAHs in water sediments from Douro River estuary and nearby Atlantic seacoast. The result showed that the global amount of PAHs $\left(\sum_{16} \mathrm{PAHs}\right)$ was extremely high at all sampling sites. It showed that their average concentrations attained $\approx 55 \mathrm{ng} / \mathrm{L}$ and $\approx 52 \mu \mathrm{g} / \mathrm{g}$ dry weight $(\mathrm{dw})$, in water and surface sediments respectively. This could be as a result of the presence of oil refinery, intense maritime traffic and other anthropogenic activities on the river as reported in the work. 
[23] In another work, the levels and distribution of 24 polycyclic aromatic hydrocarbons were determined in six water bodies along the coastal belt of Ghana. The average total PAHs recorded were from Pra estuary $6.3 \mu \mathrm{g} / \mathrm{L}$; Benya lagoon $7.5 \mu \mathrm{g} / \mathrm{L}$; Sakumono lagoon had $10.6 \mu \mathrm{g} / \mathrm{L}$ and Narkwa lagoon had $16.1 \mu \mathrm{g} / \mathrm{L} .12$ PAHs were reported to have been well distributed in all the coastal water analyzed, are: naphthalene, pyrene, flourene. acephnaphthene, 2-methylphenanthrene, 2,6-dimethylnaphthalene,

acephnaphthalene,

1-methylphenanthrene 2,3,5-trimethylnaphthalene, chrysene, biphenyl and phenanthrene. Highly probable carcinogens like benzo(b)flouranthene, benzo(a)anthracene and benzo(j,k) flouranthene were detected in some of the water bodies [24]. In another work, the contamination and toxicity level of 18 polycyclic aromatic hydrocarbons were evaluated in the sediments of langkaawi. Concentration of total PAHs were found to range from $869 \pm 00$ to $1637 \pm 20 \mathrm{ngg}^{-1}$ with a mean concentration of 1167.00 $\pm 24 \mathrm{ngg}^{-1}$, lower than the SQG affects range-low $\left(3442 \mathrm{ngg}^{-1}\right)$. The results showed non acute biological damage effect.

\section{Bioconcentration of Polycyclic Aromatic Hydrocarbons in Fish Species}

[25] PAHs levels were reported in two commercially important fish species from crude oil polluted waters of Ogoniland, Nigeria, namely: Tilapia queneesis and Liza falcipinis. Though the PAHs level ranged from below detection limit of 0.0001 to $120 \mathrm{\}} 1.18 \mu \mathrm{g} /$ $\mathrm{kg} \mathrm{wt} / \mathrm{wt}$ and 0.0001 to 78.6$\} 1.28 \mu \mathrm{g} / \mathrm{kg}$ wet wt in both fish respectively, highest average concentration was recorded for Benzo[b] Fluoranthene. High molecular weight PAHs (HMWPAHs) were generally predominant compared to low molecular weight PAHs (LMW-PAHs).

[26] The levels of polyaromatic hydrocarbons in processed fish samples namely, Smoked Fish (SF), Sundried (SD) and fried (FD) marketed in Makurdy, Benue state, Nigeria. The six-membered ring PAHs in smoked fish was $32.07 \%$ (with Bezo(ghi)perylene as most dominant). The result also showed high levels of six member ring PAHs (Dibenz(a,h) anthracene) in Sundried fish while fried fish contain Dibenz(a,h) anthracene. Similarly. In another development, [11] five different fish samples, fresh and smoked, bought from Mushin market in Lagos State, Nigeria, were sampled for polycyclic aromatic hydrocarbon (PAH) contaminants. The levels of PAHs ranged from $0.004 \mu \mathrm{g} / \mathrm{kg}$ for acenaphthene in dry M. pontassou to $2.275 \mu \mathrm{g} / \mathrm{kg}$ for phenathrene in dry S. scombrus... Smoking increased the levels of PAHs in the fish samples. These results show that PAH levels in the fish samples are higher than the permissible limit set by the World Health Organization (WHO) and the Agency for Toxic Substances and Disease Registry (ATSDR). The implications of these contaminants in the environment together with their associated health hazards are also examined. [27] In consonance with aforementioned findings, a research conducted on the levels of polycyclic aromatic hydrocarbons in fresh fish and smoked body parts of Clarias gariepinus in Nigeria and also the effects of smoking on the PAH level. From the result, The mean PAHs concentration ranged from $0.0005 \mu \mathrm{g} / \mathrm{kg}$ [indeno (1,2,3-cd)pyrene] to $2.24 \mu \mathrm{g} / \mathrm{kg}$ (fluoranthene, pyrene) and $0.0009 \mu \mathrm{g} / \mathrm{kg}$ [indeno(1,2,3-cd)pyrene] to $10.2 \mu \mathrm{g} / \mathrm{kg}$ (pyrene) for fresh and smoked fish samples respectively. The result revealed that high significant PAHs levels in smoked fish than in fresh fish.

[28] Another researcher took another dimension to assess the contamination level of PAHs in sprats and also observed the changes in its levels during storage in various types of packaging. The result had it that the amount of polycyclic aromatic hydrocarbons (PAHs) in smoked sprats varies from the level below the lowest detection limit in muscles up to $9.99 \mu \mathrm{g} \mathrm{kg}^{(-1)}$ of benzo[a]pyrene $(\mathrm{BaP})$ in fish skin while mean $\mathrm{BaP}$ level was at $1.69 \mu \mathrm{gg}^{(-1)}$. Analysis of the packaging used showed a significant increase in the level of 16 PAHs. Results from the analysis of highdensity polyethylene packaging showed six fold increases in the total 16 PAHs compared to the blank sample.

[29] Human health risks assessment of polycyclic hydrocarbons in smoked fish species from markets in southern Nigeria was carried out. The analysis showed varying levels of PAHs congeners in the fish tissues with the highest total concentration in Scomber scombrus. Highly ranked PAH-carcenogen, benzo(a)pyrene was observed in Clarias gariepinus and Ethmalosa fimbriata with values above the guideline value of $0.05 \mathrm{mg} / \mathrm{kg}$. the result showed Dietary Daily Intake (DDI) values of individual PAH congeners above the recommended reference dose for all the fish species. The carcinogenic toxic equivalents (TEQ) indicated that consumption of E. fimbriata has a higher potential to cause carcinogenic risks. TEQ values for all the fish species were above the estimated screening value (SV) of $0.022 \mathrm{mg} / \mathrm{kg}$, while the estimated excess cancer risk (ECR) and PAHs index exceeded threshold values indicating potential carcinogenic risk from consumption. [30] Polycyclic Aromatic Hydrocarbons were assessed among 5 fish species from Mumbai Harbour, India out of which mandeli, coilia, dussimieri, had the maximum concentration, followed by doma, otolithes ruber. The result from the study showed that, the concentration total and carcinogenic PAHs ranged from 17.43 to $70.44 \mathrm{ng} / \mathrm{g}$ wet wt. and 9.49 to $31.23 \mathrm{ng} / \mathrm{g}$ wet wt, respectively. According to repport, fish from Mumbai in India as at the time of this research pose potential cancer risk. This work also confirmed the ubiquitous and persistence nature of PAHs.

\section{Conclusion}

As man's quest for comfort in his ecosystem increases, the resultant impacts of his innovations and activities on the environment become inevitable. The presence of PAHs in fish, water and sediments of the aquatic environment was reported in this review and this information can't be neglected. The concentration of PAHs has direct relationship with human activities. A continuous environmental monitoring and control of PAHs in the environment for sustainable development is advised. 


\section{References}

1. Bhatia SC (2011) Environmental Chemistry. Cbs publishers and pvt. India, pp. 1-12.

2. King RP, Jonathan GE (2003) Aquatic Environmental Perturbation and Monitoring; Africa Experience USAMar. Pollut Bull American International Journal of Contemporary Research (58): 663-678.

3. Takeuchi I, Miyoshi N, Mizukawa K, Takada H, Ikemoto T, et al. (2009) Biomagnification profiles of polycyclicaromatic hydrocarbons, alkylphenols and polychlorinated biphenyls in Tokyo. Intl J of Oceanography, pp. 1-6.

4. Gerald Rhodes, Richard B Opsal, Jon T Meek, James P Reilly (1983) Analysis of polyaromatic hydrocarbon mixtures with laser ionization gas chromatography/mass spectrometry. Analytic Chemistry 55(2): 280-286.

5. Kpobari WN, Mathew OW, Eka BE (2013) Assessment of Polycyclic Aromatic Hydrocarbons (PAHs) Levels in Two Commercially Important Fish Species from crude oil polluted Waters of Ogoniland and Their Carcinogenic Health Risks. Journal of Environment and Earth Science 3(8): 1-7.

6. (2008) European Food Safety Authority (EFSA), Findings of the EFSA Data Collection on Polycyclic Aromatic Hydrocarbons in Food, in A Report from the Unit of Data Collection and Exposure on a Request from the European Commission.

7. Srogi K (2007) Monitoring of environmental exposure to polycyclic aromatic hydrocarbons: A review. Environ Chem Lett 5(4): 169-195

8. Igwe JC, Odo EO, Okereke SE, Asuqou EE, Nnorom IC, et al. (2012) Levels of Polycyclic Aromatic Hydrocarbons (PAHs) in Some Fish Samples from Mushin Area of Lagos, Nigeria: Effects of Smoking. Terrestrial and Aquatic Environmental Toxicology 6(1): 30-35.

9. Boonyatumanond R, Murakami M, Wattaykorn G, Togo A, Takada H (2007) Sources of polycyclic Aomatic Hydrocarbons (PAHs) in street dust in a typical asian mega-city, Bangkok, Thailand. Science of the Total environment 384(1-3): 420-432.

10. Otto A, Manzetti S, Szytow JT (2013) Paths and degradation of PAHs in the Environment. International Symposium on Polycyclic Aromatic.

11. Kishu GC, Tripathi S, Raj A (2018) Polycyclic Aromatic Hydrocarbons (PAHs) in environment and Human Health: A Review. Intl Journal of Advanced Research (IJAR) 6: 287-296.

12. Mahua S, Ayako T, Kaoruko M, Michio M, Hideshige T, et al. (2009) Sources of sedimentary PAHs in tropical Asian waters: Differentiation between pyrogenic and petrogenic sources by alkyl homolog abundance. Marine Pollution Bulletin 58(2): 189-200.

13. Wania F, Mackay D (1996) Tracking the distribution of persistant organic pollutant. Environ Sci Technol 30(9): 390A-396A.

14. Archibong RA, Hood DB (2012) Global Environmental Distribution and Human Health Effects of Polycyclic Aromatic Hydrocarbons.

15. Shafy PIA, Mansour MSM (2016) A review on polycyclic aromatic hydrocarbons: Source, environmental impact, effect on human health and remediation. Egyptian Journal of Petroleum 25(1): 107-123.

16. Akhbarizadeh R, Moore F, Keshavarzi B, Moeinpour A (2016) Aliphatic and polycyclic aromatic hydrocarbons risk assessment in coastal water and sediments of Khark Island, SW Iran. Marine Pollution Bulletin 108(1): 33-45.
17. Asagbra MC, Adebayo AS, Anumudu CI, Ugwumba OA, Ugwumba AAA (2015) Polycyclic Aromatic in Water, Sediment and Fishes from the Warri River at Ubaji, Niger Delta, Nigeria. J Fish Res Bd Can 36: 270279.

18. Akan JC, Chellube ZM, Mohammed AI, Ogugbuaja VO, Abdulrahman FI (2018) Polycyclic Aromatic Hydrocarbon Levels and Risk Assessement in Water, Sediment and Fish samples from Alau Dam, Borno State, Nigeria. Journal of Environmental Science and Technology 11(3): 139146.

19. Malik A, Ojha P, Singh KP (2008) Distribution of polycyclic aromatic hydrocarbons in edible fish from Gomti river, India. Bulletin of Environmental Contamination and Toxicology 80(2): 134-138.

20. Itodo AU, Nnodim VO, Ande S, Itodo HU, Ofoegbu O (2020) Levels of Polycyclic Aromatic Hydrocarbons (Pahs) In Fish Samples from Different Processing Methods. Journal of Chemical Society of Nigeria 45(6).

21. Liang Y, Tse MF, Young L, Wong MH (2007) Distribution patterns of polycyclic aromatic hydrocarbons (PAHs) in the sediments and fish at Mai Po Marshes Nature Reserve, Hong Kong. Water Research 41(6): 1303-1311.

22. Al Saad HT, Al Timari AA (1989) Distribution of polycyclic aromatic hydrocarbons (PAH's) in marsh sediments, Iraq. Bulletin of Environmental Contamination and Toxicology 43(6): 864-869.

23. Essumang DK (2010) Distribution, levels and risk assessment of polycyclic aromatic hydrocarbons (PAHs) in some water bodies along the coastal belt of Ghana scient. Scientific World Journal 10: 972-985.

24. Adeyeye EI, Ibigbami OA, Adesina AJ, Olatoye RA, Gbolagade AY (2018) Polycyclic Aromatic Hydrocarbons in Fresh and Smoked Body Parts of Clarias gariepinus (Burchell, 1822) and the Possible Risks to Human Health. Polycyclic Aromatic Compounds 40(3): 898-913.

25. Kuźmicz K, Ciemniak A (2017) Assessing contamination of smoked sprats (Sprattus sprattus) with polycyclic aromatic hydrocarbons (PAHs) and changes in its level during storage in various types of packaging. Journal of Environmental Science and Health Part B 53(1): $1-11$.

26. Tongo I, Ogbeide O, Lawrence E (2016) Human Health Risk Assessment of Polycyclic Aromatic Hydrocarbons (PAHs) in Smoked Fish Species from Markets in Southern Nigeria. Toxicology Reports 4: 55-61.

27. Dhananjayan V, Muralidharan S (2012) Polycyclic Aromatic Hydrocarbons in Various Species of Fishes from Mumbai Harbour, India, and Their Dietary Intake Concentration to Human. International Journal of Oceanography 2012(645178): 1-6.

28. USEPA (2008). United States Environmental Protection Agency. Polycyclic Aromatic Hydrocarbons (PAHs). Office of Solid wastes, Washington DC. USA, pp. 1-3.

29. Nasher E, Heng LY, Zarkara Z, Surif S (2013) Assessing the Ecological Risks of Polycyclic Aromatic Hydrocarbons in Sediments at Langkawi Island, Malaysia. Sci World.

30. Fasina AO (2012) Socio-Economic Analysis of Artisanal Fisher Folks in Ogun Water-Side Local Government Areas of Ogun State, Nigeria. Global Journal of Science Frontier. 
Your next submission with Juniper Publishers will reach you the below assets

- Quality Editorial service

- Swift Peer Review

- Reprints availability

- E-prints Service

- Manuscript Podcast for convenient understanding

- Global attainment for your research

- Manuscript accessibility in different formats ( Pdf, E-pub, Full Text, Audio)

- Unceasing customer service

Track the below URL for one-step submission https://juniperpublishers.com/online-submission.php 